\title{
French Supreme Court rules fashion shows protected by copyright-what about the UK?
}

Roberts A. D. et al. v Chanel et al., French Court of

Cassation, 5 February 2008

The French Court of Cassation has held that fashion shows can be protected by copyright.

\section{Legal context}

Article L. 112-1 of the French Intellectual Property Code provides that all works of the mind are protected whatever their genre, form of expression, merit, or purpose, provided that they are original. Article L. 112-2 enumerates a non-exhaustive list of copyrightable works.

\section{Facts}

The French Federation of Couture elaborated a strict system in order to monitor the use of photographs taken during fashion shows. Only press organizations which agree to its standard contract terms are allowed to use them and only for information purposes excluding any commercial purposes. The latter sign a 'press commitment' in which they designate a number of photographers of which they ask the accreditation by the Federation. The Federation then sends invitations to accredited photographers, who are allowed to the shows to take photographs.

These photographs can only be reproduced or communicated to the public for the press organization for whom the photographers have been accredited. Several professional photographers, who had been invited to fashion shows and had been allowed to take photographs only for the specific press organizations which requested them, subsequently uploaded the photographs as well as videos of the shows on a website.

By way of background to this case, the French Federation of Couture and several haute couture companies (including Chanel, Christian Dior, and Hermes) complained to the central unit for the repression of industrial and artistic infringements, following which the French equivalent of the Criminal Prosecution Service sued the photographers for copyright infringement. They were not found guilty at first instance, but the Paris Court of Appeal reversed the decision and held that they infringed the copyright not only in the claimants' clothes but also in the fashion shows themselves. They were both found guilty of a criminal offence and obliged to indemnify the civil parties, who had joined the lawsuit.

\section{Analysis}

Before the Court of Cassation, the defendants argued that making the photographs available on the internet was allowed by the exception for the purposes of reporting current events (Article L. 122-5, 98 of the French Intellectual Property Code, as amended by Law no. 2006-961 of 1 August 2006, which implemented the so-called InfoSoc or Copyright Directive 2001/29). This article provides that the author cannot prevent the reproduction or communication 
to the public, in whole or in part, of a

graphic, plastic, or architectural artistic work, in the written, audiovisual, or online press, for the exclusive purpose of immediately informing and in direct relation with this information, as long as the author's name, is clearly indicated. They also argued that they had implicit authorization to communicate the works to the public. In a few paragraphs, the Court of Cassation simply dismissed the photographers' appeal by stating that the Court of Appeal had legally justified its decision.

\section{Practical significance}

The decision may sound surprising to a common lawyer but it is hardly so for a French one. In civil law countries, author's right laws generally have an open list of works so that, so long as a creation is original, it is protected. Perfumes have recently provided a prime example in France and the Netherlands. This case shows once again the flexibility of continental laws and the potentially long list of creations which can obtain protection through the very generous author's right regimes. In fields related to the subject-matter in Roberts v Chanel, hair styles for instance have already been long protected [see A Lucas and $\mathrm{HJ}$ Lucas, Traité de la propriété littéraire et artistique (Paris: Litec, 2nd edn, 2001) p. 116 citing CA Aix, 11 June 1987, Cahiers de droit d'auteur, January 1988, p. 23] and French literature had already argued that fashion shows were protectable [eg PY Gautier, Propriété littéraire et artistique (Paris: PUF, 4th edn, 2001) p. 88].

Fashion shows appear to fall within the 'category' of choreographic works for which, surprisingly (there being no fixation requirement in France or in most civil law countries), Article L. 112-2-4 of the French Intellectual Property Code provides that they must be fixed. The question is whether this is a matter affecting the subsistence of copyright as such or only an evidential issue. The literature prefers this second interpretation (see Gautier, above, p. 88 and Lucas, above, p. 125). This would not have been important in this case as, even if the designers had not previously fixed their shows, and the copyright in the shows would not have subsisted, the copyright in the clothes would still have been infringed by the photographs and videos. Indeed, the clothes themselves fall within Article L. 112-2-14, which lists creations of the seasonal industries of dress and articles of fashion as protectable subject-matter.

The argument based on the exception for the purposes of reporting current events is also of interest. It was clear that the photographers could not argue that they had an implicit authorization as they were aware of the accreditation process and the strict conditions of use of the photographs. As the photographs were available both gratis and for sale on the website, this may be the reason why the court may have been inclined to refuse the application of the exception for the purposes of reporting current events. However, it would have been interesting to see what the court would have decided if the photographs had been posted on the website exclusively free of charge. The photographers uploaded them a few days after the shows (which took place between 6 and 10 March 2003) 
and, for some, even on the day of one of the shows. They were discovered on 10 March and seemingly taken down shortly afterwards as this is when the fashion houses asked for the intervention of the central unit. So arguably the condition of immediacy was present.

The wording of the exception is broad. Anyone can communicate any graphic, plastic, or architectural artistic work, so long as it is exclusively for information purposes. Even if the shows themselves are not falling into those categories, clothes are arguably graphic works, albeit in three-dimensional form. Exceptions have not been made imperative in the Directive and France has no specific provision mandating the respect of exceptions in contracts. So perhaps the Court of Cassation's decision implies that the contract binding the photographers could legally override the exception.

In a comparative outlook, this case raises the question whether fashion shows can be protected in the UK. It could be argued that they are dramatic works (choreographies) since the models have to walk in a certain order, presumably showing a string of similar clothes in a first round, then another string in a second and so on. This would certainly be considered original. It is difficult to show that there is a story but, undoubtedly, there is action, and a planned one (as opposed for instance to sport games).

As opposed to television shows and formats, there is also sufficient unity for the show to be performed again. Otherwise, following Shelley v Rex Features ([1994] EMLR 134), such undeniably highly artistic clothes would definitely be protected under the category of works of artistic craftsmanship. In addition to being artistic, haute couture clothes are generally made by hand, a condition which seems to be required (see George Hensher Ltd v Restawile Upholstery (Lancs.) Ltd [1976] AC 64 (HL); Guild v Eskandar [2001] FSR 38). The Guild v Eskandar above and Merlet v Mothercare [1986] RPC 115 cases are less on point as they dealt respectively with unoriginal and purely functional clothes. Even if copyright does not help, both domestic and Community unregistered design rights are cheap and easy ways, as protection, like copyright, arises automatically. The British unregistered design right only protects three-dimensional designs but the unregistered Community design right also protects two-dimensional ones (this including therefore dress patterns). They last for quite a long time, in view of the industry in question, respectively between 10 and 15 years, and 3 years.

Well-to-do fashion houses can also opt to transform their unregistered Community designs into a full-blown monopoly right by registering them at the Office for Harmonisation in the Internal Market (OHIM). Contrary to what a patent and trade mark attorney claims in a recent press article discussing the issue within the context of the recent London fashion week (see F McBride, 'Designers in copyright frays' The Times, 12 February 2008, available at http://business.timesonline.co.uk/tol/business/ law/article3349354.ece (accessed on 13 February 2008), where the author warns fashion houses to protect their collections against copying by high-street retailers, a practice which seems to have recently grown), even if 
designers have disclosed their design to the public they have not lost their right to apply for a registered Community design right. They have one year from the first communication of the design to the public to register it. So

fortunately for designers, they have much longer to transform their anti-copying right into a monopoly right than Cinderella's split-second to turn back to retrieve her shoe at the ball. If they still want yet more protection, and while waiting for an improbable European harmonization on protected subject-matter, British lawyers and creators may want to get around the possible lack of protection of fashion shows in the UK by providing that French law applies in contracts with fashion photographers, although that may be a law that British courts might then not want to apply. Nevertheless, it is virtually costless and always worth a try.

Estelle Derclaye

University of Nottingham

Email: estelle.derclaye@nottingham.ac.uk

Journal of Intellectual Property Law \& Practice, 2008 